\title{
The Moderating Effect of Collective Action in the Relationship between Civic Engagement and Water Service Delivery in Kondoa District, Tanzania
}

\author{
Sulley Benedict Anselm \\ Local Government Training Institute (LGTI), Dodoma Tanzania \\ Department of Community Development \\ E-mail: ben_sulley@yahoo.com \\ Nguyahambi Ajali Mustafa \\ Department of Political Science and Public Administration-University of Dodoma \\ P.O. Box 259 Dodoma, Tanzania \\ E-mail: ajalimu@yahoo.co.uk
}

Kilonzo Rehema Godfrey
Department of Sociology and Anthopology- University of Dodoma

P.O. Box 259 Dodoma, Tanzania

E-mail: kilonzo_rehema@yahoo.com

Received: Aug. 3, 2020 Accepted: Sept. 14, 2020 Online published: Oct. 11, 2020

doi:10.5296/jpag.v10i3.17471 URL: https://doi.org/10.5296/jpag.v10i3.17471

\begin{abstract}
Civic engagement has been an area of research after adoption as an important approach to strengthen citizens' voice, accountability and communication in public service delivery. However, there is mixed result on its relationship with public service delivery, particularly water services. Civic engagement studies consider collective action as critical success factor in public service delivery. Therefore, this study focused on testing the moderating effect of collective action on the relationship between civic engagement and water service delivery in Kondoa District Council of Tanzania using a cross-sectional design with a sample of 376
\end{abstract}


households. Cronbach's alpha value was above 0.7 , which was considered good and acceptable. The moderated binary logistic regression was used for data analysis. The analysis confirms the significant moderation effects of collective action on the relationship between citizens' voice and all three-outcome variables, physical accessibility, quality, and quantity of water supplied. Similarly, collective action had a significant moderation effect on the relationship between accountability and domestic water service delivery variables except for the quantity of water supplied. Moreover, the effect of collective action in the relationship between communication and all the variables of water service delivery is not significant. The study concluded that the influence of civic engagement in water service delivery will be effective when citizens are organised into collective action. The study recommends that civic engagement should be strengthened through tailor-made training and mentorship to implant collective action attributes to citizens on issues of public concern, i.e. water service delivery and management.

Keywords: civic engagement, collective action, citizens' voice, and accountability

\section{Introduction}

There is a global call for civic engagement (henceforth CE) mechanisms to transform citizens into active participants in scaling up water service delivery. This is because there is a depressing state of water service delivery in Sub-Saharan Africa. This failure is not a result of the lack of interventions but a failure of the mechanisms used in solving the problem facing the sector (Mugumya, 2013; Nganyanyuka, 2017). In traditional democracy, citizens elect representatives whose role is to hold bureaucrats accountable for executing decisions they made of behalf of the people (Mollah, 2008). Today, most citizens no longer want to be considered as clients in the representative democracy but active participants (Leighninger, 2005; Sarker, 2008). The relevant mechanism to engage citizens is what Hirschman (1970) called 'voice'. This is an engagement mechanism that has a focus on strengthening accountability by giving citizens control over resources, oversight of the government functions, and genuine communication with the government to accommodate the marginalized groups (Tshoose, 2015). In that case, mainstreaming civic engagement in decision-making processes compensated representational gaps. With this importance, developing countries, in Asia and Africa, including Tanzania, undergo major policy shifts from supply-driven to demand-driven approaches to ensure the sustainability of public services (Sarker, 2011; Mugumya, 2013).

Tanzania has been promoting civic engagement in Local Government Authority (LGAs) as policy instrument to address local needs and empower people for service delivery. In the water sector, specifically civic engagement initiatives are enshrined in the formulation of National Water Policy (NAWAPO) (2002), National Water Resources Management Act (NWRMA) No. 11 of the year 2009, Water Supply Act (WSA) No. 12 of the year 2009 to provide enabling environment to promote civic engagement in delivery and management of water services. The policy aims at ensuring that beneficiaries actively participate in planning, construction, operation, maintenance, and management of community based domestic water supply schemes (NAWAPO, 2002). The target of the policy was to improve physical access to 
water points in 30 minutes walking distance to and from the homestead, access to quality water from improved water sources and improve quantity per individual, i.e. 25 litres per day. The goal is to increase access to water to rural areas, i.e. from 53\% in 2006 to $90 \%$ by the year 2025 (URT, 2006). Despite these changes in policy, laws, institutions, and significant investments, the status of water service delivery remained stagnant in Tanzania. The current report indicated that, on average, $53.4 \%$ of the population lacked access to water services (National Bureau of Statistics, 2017). This is almost the same level of access that was reported back in 2006. More to these, around 18,500 under-five children die from diarrhoea every year. Around $90 \%$ of these deaths result from poor water hygiene (Kessy \& Mahali, 2016). The situation is worse in the study area (Kondoa District) where only $31.6 \%$ of the population fetching water within a target of 400 meters (KDC, 2016).

The literature on civic engagement practices has been criticized for disregarding the influence of contextual factors or the operating environment that standoff the expected goal of civic engagement. The Principal-Agent theory postulates that successful and meaningful engagement is determined by the power of citizens in decision-making. The theory is, however, criticised for its failure to consider context or the problems of collective action that emanate from people's interest due to cultural diversities. The theory of collective action recognises the problems of collective action that arise from people's interest in terms of class, gender, income, wealth and other many elements of identity and social stratification. Guijt and Shah (1998) and Katz et al. (2004) asserted that development challenges in developing countries are associated with the problems of collective action. According to Ostrom (1996), collective action refers to personal beliefs and feelings that individuals have about their involvement in issues of public concern and the perceived ability to make a difference in that service delivery. This considers the cultural differences in collective action between countries and diverse societies (Brinkerhoff, 2015). The literature stresses that people's conduct, attitude, and action performed daily are the outcomes of what someone has learned in a particular environment (Hofstede, Hofstede, \& Minkov, 2005). Mugumya (2013) asserted that engagement faces the challenges of collective action because citizens struggle to meet their own needs rather than public goals. This raised the concern of whether civic engagement alone is adequate to predict the performance in water service delivery.

\section{Empirical Literature Review}

\subsection{Definitions of Key Concepts}

\subsubsection{Civic Engagement}

Existing studies suggest that the term civic engagement is multidimensional as it means to varieties of citizens' actions. Some scholars conceive civic engagement as involvement in the organizations, such as civic clubs and groups, giving donations, volunteering and holding public officials accountable (Leighninger, 2005; Sarker, 2008; Karakos, 2015). Others consider it as a voting involvement, involvement in political issues, expressing opinions through letters, watching television (Opoku-agyeman, 2013; Sargsyan, 2016). Civic engagement is also defined as process in which people take collective action to address issues of public concern (Della Porta, 2013; UN, 2008). All these definitions of civic engagement 
are converged to a definition doable in this study to mean a process through which citizens directly interact or collaborate with the government to share control, decisions, and resources to address issues of the public concern. This study, specifically, concentrated on the mechanisms, such as citizens' voice, accountability, and communication as an avenue for civic engagement in water service delivery.

\subsubsection{Citizens' Voice}

Goetz and Gaventa (2001) define voice as a variety of mechanisms (formal or informal) used by citizens to expresses their views and influence governments' priorities and processes. Several countries in Africa and Asia have adopted decentralization in the attempt to introduce voice mechanisms into their government systems in a venture to improve the deliverance of social services. A few to mention here include India, Malaysia, Philippines, South Africa, Uganda and Tanzania (Andrews \& Shah, 2002). The general assumption here was that giving voice to the needs, harvesting their opinions, and concerns would help the government to better understand citizens' priorities and how to serve them better. The channels through which citizen's voice is expressed are through public meetings, public hearing, public complain desk and participatory forum. These mechanisms are a common way of strengthening a new democratic spirit, motivating and facilitating reforms and improvement of service delivery. The main concept here is putting citizens at the centre of the political process that is 'voice' cantered rather than 'vote' cantered.

\subsubsection{Accountability}

The concept of accountability is multi-dimensional in character (Mulgan, 2000). In that regard, political scientists establish sub-types of accountability in relation to different nature of actors based on three dimensions, such as vertical, horizontal, and diagonal accountability (Lührmann, Marquardt, \& Mechkova, 2017; Sharma, 2008). Under vertical accountability, citizens can hold their government accountable through mechanisms, such as elections and political parties. On the other hand, horizontal accountability, state institutions such as legislature and judiciary oversee the functions of executive branch of the government. As for the diagonal accountability, citizens are engaged in new watchdog functions, especially the oversight of the state functions (Goetz \& Gaventa, 2001). The current literature illuminated that failure of service delivery in the developing countries is connected with the lack of accountability relationship between citizens and government (Bellour, 2002). The central argument is that the relationship between citizens and government is not transparent and effective (Barberis, 1998; Malena, Forter, \& Singh, 2004). This study adapted the third dimension of accountability that refers to mechanisms through which citizens perform the watchdog functions (oversight) by demanding more transparency and performance from water service providers.

\subsubsection{Communication}

Basically, communication provides a forum upon which the diverse groups of people understand issues and make decisions towards common goals (Joseph, 2016). In other words, effective communication takes place when the receivers understand and take actions upon the 
message in the same way the sender intended (Byaruhanga, 2010). This study terms communication as the reciprocal interaction between citizens and government who sits for decision-making in the water service delivery processes. Communication between citizens and the Government of Tanzania has constitutional safeguards. In the Constitution of the United Republic of Tanzania (URT) of 1977, the right to seek, obtain and disseminate information is provided under Article 18 of the Constitution.

\subsubsection{Collective Action}

Culture is an essential element in our life and it is always taken for granted. Hofstede et al. (2005) cited culture as a collective programming of human mind that differentiate one group from another. The term 'collective action' means the action undertaken to achieve certain common goals (Ostrom, 1996). For the purpose of this study, collective action refers to personal beliefs and feelings that individuals have about their own involvement in issues of public concern and their perceived ability to make a difference in that service delivery.

\subsection{Civic Engagement, Collective Action, and Water Service Delivery}

In recent years, there has been increased practice of measuring water service delivery to quantify the national or global progress of interventions in the water sector. Tanzania, like many other African countries, adopted the universal access to water standards to quantify and assess the progress of the national goals. Through NAWAPO of 2002, several standards were established to measure water service delivery. The commonly used dimension and indicators in measuring water service delivery in Tanzania include physical accessibility, quality, and quantity of water. However, these measurements differ across nations and also between some international organizations. In the case of WHO, domestic water points or source has to be within 1000 meters from home, or the fetching time should not be more than 30 minutes walking distance (UNICEF/WHO, 2015). The Tanzanian NAWAPO (2002) target was to improve physical access water points in 30 minutes of walking distance to and from homestead. It also aimed to improve access to quality water and quantity per individual, i.e. 25 litres per person per day. To attain these targets, civic engagement practices have been mainstreamed in water service delivery and management since 2000. The primary target of these initiatives was to secure citizens' voice, accountability, and project ownership as the primary stakeholders in water service delivery. Civic engagement initiatives are now in the second decade as key paradigms for water service delivery and managements but the progress in the water sector remains unsatisfactory. As it stands now, $53.4 \%$ of the population in Tanzania lacked access to water services (NBS, 2017) and about $90 \%$ of the deaths of under-five children resulted from poor water hygiene (Kessy \& Mahali, 2016).

The contemporary literature has produced mixed results of the influence of civic engagement on service delivery. Some studies establish a positive relationship while others reported that there is no direct linkage. The parameters such as the ability to make financial support, attendance of the meeting, engagement in decision making were observed to be central in improving access to water services in some communities while they did not contribute to improved water services in other areas (Babajanian, 2014; Bukenya, Hickey, \& King, 2017). These findings signify that civic engagement mechanisms are not a sufficient condition due 
to some other hindering factors, such as resources and cultural differences. Agarwal et al. (2011) argued that even best-designed intervention will fail unless the context is controlled. The similar situation was observed in Tanzania by Nguyahambi and Chang'a (2019) who argued that the success of social accountability in promoting active citizenship depends on the contexts at the local level.

The study conducted in Bengel, India by Domingo (2015) shows that people's participation is affected by distance. This study revealed that the meetings are generally held in the very accessible venue, to facilitate attendance by all inhabitants of the village and town. This has facilitated different voices in the areas of the budget. The study finally concluded that giving opportunities to stakeholders in meeting facilitated transparency and smooth implementation of the budget. Another related study was conducted in India by Prokopy (2005) who investigated 45 rural water supply projects. The result indicated that household involvement in decision-making and cost contribution were associated with indicators of better water service delivery whereas household attendance at planning processes was not a contributing factor. In a study conducted in Ghana, Opoku-agyeman (2013) established that performance of government project correlates with-citizens' voices through enhanced community participation. Citizens' voice increases accountability, transparency, and greater efficiency of government actions. Gaventa and Barrett (2012) added that the most effective and efficient way of perpetuating government performance is by increasing the efficacy of citizen's voice and participation through accountability, transparency, and the rule of law. In Kenya, Muriu (2014) conducted an empirical study on the relationship between citizen participation and decentralized service delivery in Kenya. The analysis suggests that citizens' participation has minimal influence on decentralized service delivery. The study further added that, despite the dismal impact of citizen participation, the first step towards institutionalization is observed to be built on the current government structure.

The gaps of effective communication between the government and public were observed in Asia and some of the African countries. In his study, Dudley (2009) linked the lack of fulfilment of any development goals to the lack of effective communication. This study noted the gap to be bridged by attaining effective citizen participation and service delivery. A similar study conducted in China by Lu (2009) revealed that ineffective communication has a negative impact on development initiatives in local governments. The UN (2014) added that ineffective communication leads to poor transparency and accountability that finally affect the level of public service delivery. Another study by Olomola et al. (2012) in Nigeria identified that many participants at the grassroots level have poor education and finds it difficult to make a meaningful contribution to discussion and fundamental decisions. The people who have little education were rendered powerless. The poor villagers with less or no education find it difficult to comprehend what is said and agreed in the public meeting because official speak higher language that creates a gap of misinformation.

According to Guijt and Shah (1998) and Katz et al (2004), development challenges in developing countries are associated with collective action problems. According to Meinzen-Dick et al. (2004), the collective action should be voluntarily undertaken the members of the community themselves to achieve their common interest. Peiffer and 


\section{MIMacrothink}

Journal of Public Administration and Governance

ISSN 2161-7104

2020, Vol. 10, No. 3

Marquette (2015) added collective action to achieve the public concern that self-designed rules are crucial for the management of common pool resources without state inference. The study conducted in Aktsi District in Ghana, by Gbedemah (2010), found that people resist payment of $5 \%$ for the construction of water families due to the problems of collective action. This is due to fact that many people in Aksi District lack the commitment to participate in the public meeting. The study conducted in Filipino by Dominik et al. (2004) explains that when it comes to issues of public concern, there is situation called "kanya kanya syndrome" which means each man for himself. The people feel that it is better to deal with family matters rather than collective responsibility.

The findings of the previous studies on the influence of civic engagement on service delivery have produced a set of mixed results with some studies support the positive relationship while others have reported no direct linkage. Even when the results show the existence of a relationship, the relationship seems to be weak. Inconsistent findings in the literature raise a question of whether the direct influence of civic engagement alone is adequate to predict performance in water service delivery. Therefore, this study attempted to fill the gap in the literature by answering the question of whether the relationship between civic engagement and water service delivery is moderated by the subject collective action.

\subsection{Conceptual Framework}

The literature yielded a conceptual framework that indicated the operational variables used. The conceptual framework shows that the relationship between civic engagement mechanisms (citizen's voice, accountability, and communication) and water service delivery indicators (i.e. physical accessibility, quality, and quantity) is moderated by the subject collective action. The framework was informed by Baron and Kenny's (1986) approach to testing moderation in the relationship between the variables. The framework suggests that the causal relationship between two variables (X and $\mathrm{Y}$ ) changes as a function of the moderator (Z). Figure 1 below illustrates the interaction between independent, moderator, and dependent variables.

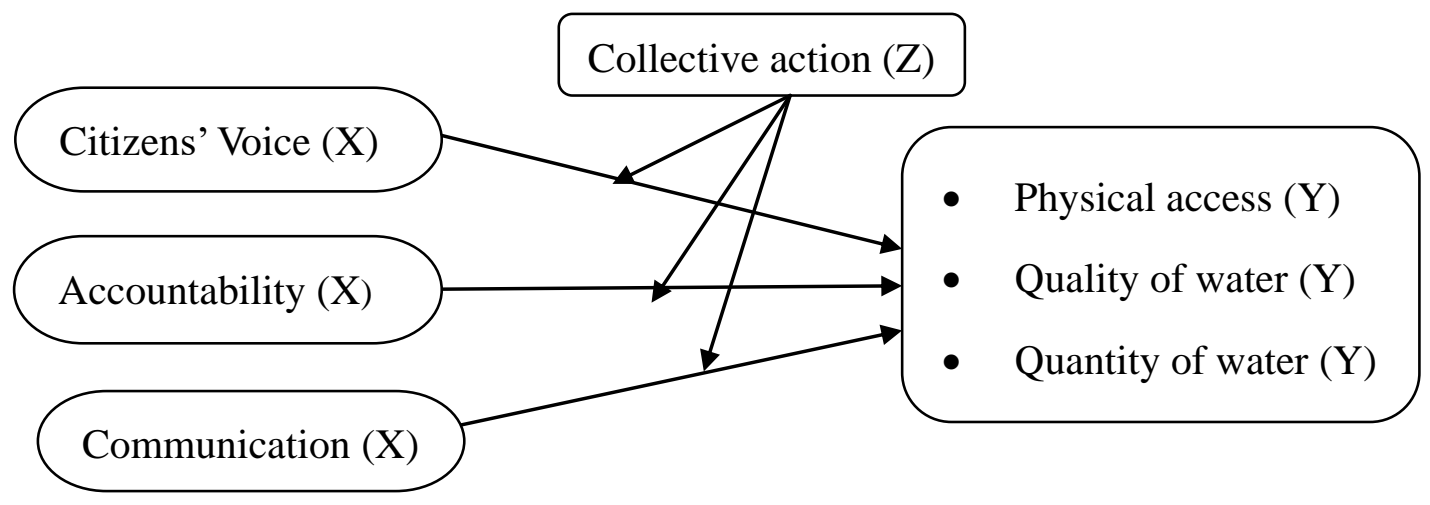

Source: Researcher's own Design

Figure 1. Moderated Effect of Collective Action (Z) in Relation between X and $Y$ 


\section{Material and Methods}

\subsection{Research Design}

This study employed a descriptive cross-sectional design. The design is characterized by its ability to describe phenomena in association with the population of the study. In a cross-sectional survey, independent and dependent variables are measured at the same point in time (Bhattacherjee, 2012; Cooper \& Schindler, 2006). A descriptive cross-sectional design was used in this study to examine the relationship between civic engagement, collective action, and water service delivery. Munjuri (2013) and Oluoch (2014) used a similar research design which generated satisfactory research results.

\subsection{Study Population}

The target population for this study was 6126 households from two Wards Kikore and Mnenia in Kondoa District Council. The population of this study was all members who benefit from water services in Kondoa District. According to Castillo (2008), population must bear the characteristics questioned in the study. The units of analysis were the head of households with the assumption that they are the best units of measuring accessibility, quality, and quantity of water services. A household in this study is defined as a unit consisting of one or more people who live in the same dwelling and share meals.

\subsection{Sampling Techniques}

Both purposive and stratified random sampling techniques were employed to select a relevant study area and the respondents to be involved in this study. Dodoma Region was purposively selected on the premise that it ranks the top among the regions experiencing water shortage (Mkonda, 2015). Specifically, Kondoa District was selected out of eight districts found in Dodoma Region because it was piloted at the initial development of the National Framework for participatory planning and budgeting, namely "Opportunity and Obstacle to Development"(O \& OD) in 2001 (Kawa, 2003). Silverman (2006) and Patton (1990) suggested for selection of areas like this for research because they are information-rich. The household heads who responded to the questionnaires were identified through stratified random sampling technique. The villages included in this study were considered as strata. The proportionate stratified sampling was used to draw a sample from nine (9) villages from Mnenia and Kikore Wards of Kondoa District. The sample was drawn from all villages of the selected Wards because of inter-village variation (heterogeneous) in terms of water infrastructure. Yamane (1967) formula was used to generate the sample size from the population of 6126 households taken Mnenia and Kikore Wards. A sample of 376 heads of households was proportionally selected for the administration of the questionnaire.

$$
\mathbf{n}=\frac{\mathbf{N}}{\mathbf{1}+\mathbf{N}\left(\mathbf{e}^{2}\right)}
$$

Subjecting these statistics into the formula, generated a sample 376 household heads.

$$
\mathrm{n}=\frac{6126}{1+6126\left(0.05^{2}\right)}=376
$$


Table 1. Proportionate Sample Distribution

\begin{tabular}{llcc}
\hline Wards & Villages & $\begin{array}{l}\text { Number-of } \\
\text { Households }\end{array}$ & $\begin{array}{c}\text { Proportionate } \\
\text { Sample Size }\end{array}$ \\
\hline Mnenia & Mnenia & 767 & 47 \\
& Mbambare & 696 & 43 \\
& Itudwi & 742 & 45 \\
Sub Total & Filimo & 344 & 21 \\
Kikore & Kikore & $\mathbf{2 5 4 9}$ & $\mathbf{1 5 6}$ \\
& Madege & 691 & 42 \\
& Hurui & 190 & 12 \\
& Mitati & 876 & 54 \\
& Mkurumuzi & 944 & 58 \\
Sub Total & & 876 & 54 \\
Grand Total & & $\mathbf{3 5 7 7}$ & $\mathbf{2 2 0}$ \\
\hline
\end{tabular}

Source: Ward Households Register, 2019

\subsection{Data Collection and Analysis}

The data regarding civic engagement, water service delivery indicators and collective action were generated through questionnaire. To ensure the validity of the research pre-existing questionnaire was adopted from Doolittle and Faul (2013) and Naidoo (2017). The questionnaire was further customized to suit the context of this study. The questionnaire contained closed ended questions with response categories, such as Likert scale and binary choices. The 5- point Likert (ranged from 1=strongly disagree to 5=Strongly Agrees) were used to rate each statement related to civic engagement mechanisms and collective action. Arsenault and Anderson (1998) described Likert scale as an excellent means of gathering peoples' attitudes and perceptions. Also, binary choices questionnaire was used for water service delivery indicators based on accessibility, quality, and quantity of water services. Therefore, in this study, water service is either accessible for those who use $\leq 30$ minutes or otherwise, the quantity of water is either adequate for persons who use $\geq 25$ litres or otherwise. The quality of water sources was either improved or not improved. The water sources mean the piped or protected water supply into the dwelling and unimproved to mean unprotected sources of water. The current practice of the Ministry of Water (MoW) in Tanzania and National Bureau of Statistics (NBS) recognize water source type as a proxy indicator of water quality (Mwamaso, 2015).According to Saunders et al.(2012), this type of assessment is popular in measuring the user or customer satisfaction across different field.

A pilot study was conducted to refine the questionnaire prior to the actual data collection exercise so that respondents may not face difficulties in answering the questionnaires (Kothari, 2004). Pilot test is very useful to detect any problem with the questionnaire, particularly the structure, time to compete and wording (Creswell, 2014). In addition, pre-testing the questionnaire ensured validity and reliability of the findings (Saunders et al., 2012). The pilot study was conducted in Kolo Ward which is closest to the study area. Kolo 
Ward was selected because its population possesses similar characteristics with that of people in Mnenia and Kikore Wards of Kondoa District. A sample of 30 households was randomly selected from the population. Cronbach Alpha Coefficient was used to ensure internal consistency of the variables used in the study. The Cronbach's alpha values ranged from 0 to 1, the value 0.7 or higher are acceptable level of internal consistency (Cortina, 1993). The computer software (SPSS) was used to compute the reliability test and results are indicated in Table 2. The result shows that Cronbach's alpha values for variable used in this study ranged from 0.714 to 0.759 . These signify that the variables used are good to ensure adequate reliability. Therefore, the data collection tool (questionnaire) was reliable and acceptable to predict outcomes. The analysis of the pilot study findings contributed to elimination of certain questions while others were refined. In addition, the pilot study helped the study team to acquaint themselves with the contents of the tool before the actual implementation of the survey.

Table 2. Cronbach's Alpha Values and the Number of Items for Each Factor

\begin{tabular}{lcc}
\hline Items & Number of items & Cronbach's Alpha \\
\hline Voice & 7 & 0.736 \\
Accountability & 5 & 0.714 \\
Communication & 5 & 0.759 \\
Collective action & 5 & 0.730 \\
\hline
\end{tabular}

Source: Field data, 2019

As mentioned earlier, quantitative data from 376 survey questionnaires were analysed by the aid of IBM SPSS version 25. In the analysis, moderated binary regression models were used to establish the moderating effect of collective action on the relationship between civic engagement mechanisms and domestic water service delivery. The Baron and Kenny (1986) approach was used to test the moderation effect by which the dependent variable $(Y)$ is regressed against assumed moderator $(Z)$ together with the independent variable $(X)$. It was assumed that the presence of the moderation effect was to be determined by the presence of a significant effect of the interaction term $X Z$. With this specific study, $\mathrm{Y}, X, Z$, and $X Z$ represented water service delivery, civic engagement mechanisms, collective action, and interaction term respectively. The effects of collective action were considered significant if the $p$-value for interaction effects is less than 5\% level of significance. Testing moderation was guided by the moderated binary logistic regression equation. The general moderated binary logistic regression model is given as:

$$
\log i t[\pi]=\log \left(\frac{\pi}{1-\pi}\right)=\beta_{\mathrm{O}}+\beta_{1} X+\beta_{2} Z+\beta_{3} X Z
$$

Where, $\boldsymbol{\pi}(x)$ is the likelihood that water is accessible or having protected water points or having adequate, $\beta_{1}$ and $\beta_{2}$ stands for the main effect of civic engagement mechanisms and collective action respectively, while, $\beta_{3}$ stands for the moderating effect of collective action. 


\section{Results and Discussions}

This section presents the findings on the moderating effect of collective action on the relationship between civic engagement and water service delivery. The actual field data are described as per feedback from the administered questionnaire. In the course of conducting this study, civic engagement was assessed as a composite of three independent variables: citizens' voice, accountability, and communication and dependent variable water services delivery measured by three indicators physical accessibility, quantity, and quantity of water. The core assumptions are that the influence of civic engagement on water service delivery is moderated by the subject collective action. The Baron and Kenny (1986) criteria explained in section 2.4 was used to confirm the assumption guiding this study.

\subsection{The Influence of CE Mechanisms on Physical Accessibility to Water Services as Moderated by Collective Action}

A moderated binary logistic regression analysis was carried to test the moderating effect of collective action (among citizens with a positive or negative attitude towards collective action) on the relationship between civic engagement mechanisms and physical accessibility to water service. The Baron and Kenny (1986) criteria were used to test the moderating role of collective action on the effect of CE mechanisms on physical accessibility to water services. As per NAWAPO (2002), people in the rural setting are deemed to have proper access to water if they receive clean water from the distance of 400 meters or 30 minutes walking distance from their home. This study specifically used the time (30 minutes) to measure physical accessibility to water services. The results of the fitted binary logistic regression model with interaction between collective action and civil engagement mechanisms were presented in Table 3.

Table 3. The Influence of CE Mechanisms on Physical Accessibility to Water as Moderated by Collective Action

\begin{tabular}{lllll}
\hline Parameter & Estimate & Standard error & Chi square & P-value \\
\hline Intercept & -8.093 & 1.7744 & 20.8024 & $<0.0001$ \\
Voice & 1.3651 & 0.4295 & 10.1011 & 0.0015 \\
Accountability & 0.5976 & 0.2098 & 8.1135 & 0.0044 \\
Communication & 0.2087 & 0.3071 & 0.4618 & 0.4968 \\
Collective action & & & & \\
Positive & 0.5758 & 2.328 & 0.0612 & 0.8046 \\
Negative & Reference & & & \\
voice*collective action & 0.4119 & 0.1506 & 7.4806 & 0.0062 \\
Accountability*collective action & 0.2121 & 0.0949 & 4.9952 & 0.0254 \\
Communication*collective action & 0.2458 & 0.4047 & 0.3688 & 0.5436 \\
\hline
\end{tabular}

Source: Logistic regression model result

The result in Table 3 observed the significant positive interaction effect between collective action and citizens' voice $(\beta=0.4119,0.0062)$. This suggests that the influence of citizens' 
voice on physical accessibility to water based on time used to fetch water is moderated by subjects' collective action. It was noted that the influence of voice mechanism on the likelihood of using less than 30 minutes in fetching water was significantly higher among subjects with a positive attitude as compared to those with a negative attitude. Similarly, a significant positive moderating effect of collective action on the influence of accountability on time used to fetch water was observed $(\beta=0.2121, \mathrm{p}=0.0254)$. This suggests that the influence of accountability on time used to fetch water was higher among individuals with a positive attitude towards collective action than the subjects with negative attitude. However, the moderating effect of collective action on the influence of communication mechanism on physical accessibility based on walking time to fetch water was not significant $(\beta=0.2458$, $\mathrm{p}=0.5436$ ). The study revealed that collective action moderated the influence of citizen's voice and accountability on physical accessibility among the people with positive attitude towards collective action than the subjects with negative attitude. This finding is in line with Mugumya (2013) and Bukenya et al. (2017) who asserted that the relationship between civic engagement and public service delivery is not constant because individuals struggle to meet their own needs rather than the public needs. Those people with positive attitudes towards collective action have higher chances of accessing water services compared to those with negative attitude. The findings of this study also concur with the assertions of the Theory of Collective Action that positive attitude of citizens towards engagement in managing common pool resources are related to better service delivery.

\subsection{Influence of CE Mechanisms on Quality of Water as Moderated by Collective Action}

This section sought to know whether the influence of CE mechanisms on water quality is moderated by collective action. The Baron and Kenny (1986) criteria were used to test the moderating role of collective action on the effect of CE mechanisms on the quality of water. The results of the fitted binary logistic regression model for the moderating effect of collective action on the influence of civil engagement mechanisms are displayed in Table 4.

Table 4. The Influence of CE Mechanisms on Quality of Water as Moderated by Collective Action

\begin{tabular}{lllll}
\hline Parameter & Estimate & Standard error & Chi square & P-value \\
\hline Intercept & -3.492 & 1.3132 & 7.0707 & 0.0078 \\
Voice & 0.2507 & 0.1212 & 4.2786 & 0.0386 \\
Accountability & 0.3457 & 0.1694 & 4.1646 & 0.04128 \\
Communication & 0.378 & 0.1846 & 4.1930 & 0.0406 \\
Collective action & & & & \\
Positive & 1.0483 & 1.8543 & 0.3196 & 0.5719 \\
Negative & Reference & & & \\
voice*collective action & 0.522 & 0.2553 & 4.1806 & 0.0409 \\
Accountability*collective action & 0.4572 & 0.2306 & 3.9309 & 0.0474 \\
Communication*collective action & 0.296 & 0.389 & 0.5790 & 0.4468 \\
\hline
\end{tabular}

Source: Survey data, July 2019 
The results in Table 4 indicated that there was a significant positive moderating effect of collective action on the influence of citizens' voice on the quality of water based on the source type of water $(\beta=0.522, \mathrm{p}=0.0409)$. This means that the influence of citizens' voice on the likelihood of using protected sources of water was observed to be higher among subjects with a positive attitude towards collective action in comparison to individuals with negative attitudes. Also, a significant positive moderating effect of collective action on the influence of accountability on the chance of using protective sources of water was observed $(\beta=0.4572$, $\mathrm{p}=0.0474)$. However, the moderating effect of collective action on the influence of the communication mechanism on sources of water used was not significant $(\beta=0.296, \mathrm{p}=0.4468)$. This means that the proposed model could not suitably explain the moderating role of collective action on the influence of communication on the chances of getting quality water services. The overall results show the significant interaction effect of collective action (among citizens with positive attitudes) on the influence of citizens' voice and accountability on the quality of protected sources of water compared from individuals with negative attitudes. These findings inform that the chances of using improved water sources are higher among the citizens who believe in collective actions. These findings confirm the argument by Wahab (2011) that positive citizens' attitudes and beliefs depend on educational practices. Therefore, attitude change can be enhanced by civic learning were citizens can learn their rights and responsibilities. A study by Bukenya et al. (2017) reiterates that the contextual factors that hinder civic engagement include the lack of citizens' capacity and commitment to engaging in the collective forms of action.

\subsection{The Effects of CE Mechanisms on the Quantity of Water as Moderated by Collective Action}

This section sought to establish the moderating effects of collective action on the influence of CE mechanism on the quantity of water service delivered. As per to NAWAPO (2002), people in the rural setting are deemed to have proper access to water if they receive at least 25 litres of clean water per day, per person. The Baron and Kenny (1986) criteria were used to test the moderating role of collective action on the effect of $\mathrm{CE}$ mechanisms on the quantity of water service delivered. It is assumed that the presence of moderation effect was to be detected by the significant effect of the interaction term (XZ). The results of the fitted binary logistic regression model for moderating effect of collective action on the influence of civic engagement mechanisms on water service delivery are displayed in Table 5.

Table 5. The Effect of CE Mechanisms on the Quantity of Water as Moderated by Collective Action

\begin{tabular}{lllll}
\hline Parameter & Estimate & Standard error & Chi square & P-value \\
\hline Intercept & 0.1713 & 1.0675 & 0.0257 & 0.8725 \\
Voice & 0.0451 & 0.3146 & 0.0206 & 0.8859 \\
Accountability & 0.02362 & 0.2611 & 0.0082 & 0.9282 \\
Communication & -0.1708 & 0.2636 & 0.4199 & 0.517 \\
Collective action & & & & \\
Positive & 0.2228 & 1.5638 & 0.0203 & 0.8867 \\
\hline
\end{tabular}


Negative 2020, Vol. 10, No. 3

$\begin{array}{lllll}\text { voice*collective action } & 0.4661 & 0.2181 & 4.274186 & 0.0386 \\ \text { Accountability*collective } & 0.0622 & 0.3436 & 0.0327 & 0.8564 \\ \text { Communication } * \text { collective } & -0.202 & 0.3568 & 0.3205 & 0.5713\end{array}$

Source: Field Data, July 2019

The result presented in Table 5 revealed that there is a significant positive interaction effect between collective action and citizens' voice $(\beta=0.4661, \mathrm{p}=0.0386)$. This means that the influence of citizens' voice on the chance of having accessibility to at least 25 litters of water per day was significantly higher among subjects with positive attitudes as compared to those with negative attitudes. This relationship seems to agree with the Theory of Collective Action which suggests that collective action is a driving force that supports the management of common resources for the benefit of the group members. This is because it is formed on the premise that people join their effort and trusting relationship among themselves to exploit the collective ability of members, such as knowledge, resources, and information for the benefit of group interest (Katz et al., 2004). On the other hand, the moderation effects of collective action on the influence of accountability on the quantity water accessed by individuals per day is not significant $(\beta=.0622, \mathrm{p}=0.8564)$. Though not significant, the positive relationship of collective action suggests that it is a vital component for individual access water. Similarly, the influence of communication on the quantity of water accessed by individuals per day cannot be explained by the presence of collective action $(\beta=-0.202, \mathrm{p}=0.5713)$. These findings are consistent with Booth and Cammack (2013) who asserted that development challenges in developing countries are linked with collective action problems. Collective action problems emerge when individuals in a group fail to perform the collective roles to achieve the results that benefit the group. Mugumya (2013) concluded that engagement faces collective action challenges because citizens struggle to meet their own needs rather than public goals. According to Green and Kreuter (1991)), local practices and culture are important tools to shape human behaviour and attitudes towards collective action. The Theory of Collective Action supports this position with an argument that traditional self-designed institutions are basic to enable the beneficiaries to manage the use of resources by themselves.

\section{Conclusion}

This study shows how the influence civic engagement mechanisms on water service delivery are moderated by collective action. The findings confirm the significant moderation effects of collective action on the relationship between citizens' voice and all three outcome variables, i.e. physical accessibility, quality, and the quantity of water supplied. Further, collective action has a significant moderation effect on the relationship between accountability and water service delivery variables, except for the quantity of water services delivered to individuals per day. Finally, collective action has no significant moderation effect in the relationship between communication and all water service delivery variables. These findings contributed to the knowledge gap that exists between theory and practice of civic engagement in water service delivery. The findings inform the policy-makers on the specific strategies 
that could be developed to gear citizens towards common interest which, in turn, improve engagement in water service delivery. This could be implemented by developing clear strategies to support citizens through tailor-made training and mentorship to implant collective action attributes to citizens on issues of public concern, i.e. water service delivery and management.This study also contributes to synergize the Principal Agent and Collective Action theories in understanding the missing link between civic engagement mechanisms and water service delivery in LGAs. Broadly, the use of two theories provides a synergistic effect and a holistic framework for understanding and addressing the ineffectiveness of civic engagement in water service delivery in Kondoa District Council.

\section{Acknowledgement}

We acknowledge funding support for this work from both Local Government Training Institute (LGTI) and Belgium Technical Cooperation (BTC) for financing this research. Equally, we extended our appreciation to the Regional Commissioners' Office of Dodoma for granting the permission to undertake research in Kondoa District Council. Special thank to Kondoa District Council Director who introduced us to different offices from the District level to the villages where this study was conducted. Unfortunately, it is not possible to mention all the people who made their contribution to the realization of this study but we recognise and appreciate the contribution we received from everyone.

\section{References}

Agarwal, S., \& Van Wicklin, W. A. (2011). How, when and why to use demand-side governance approaches in projects: Social development how-to-notes. Washington DC: The World Bank.

Andrews, M., \& Shah, A. (2002). Voice and local governance in the developing world: What is done, to what effect, and why. Washington, DC.: Unpublished manuscript, World Bank.

Arsenault, N., \& Anderson, G. (1998). Qualitative research. In In G. Anderson \& N. Arsenault, Fundamentals of Educational Research (2nd ed.). London: Routledge Falmer.

Babajanian, B. (2014). Citizen empowerment in service delivery. Governance in developing Asia: Public Service Delivery and Empowerment, 229. https://doi.org/10.2139/ssrn.2479718

Barberis, P. (1998). The new public management and a new accountability. Public Administration, 76(3), 451-470. https://doi.org/10.1111/1467-9299.00111

Baron, R. M., \& Kenny, D. A. (1986). The moderator-mediator variable distinction in social psychological research: Conceptual, strategic, and statistical considerations. Journal of Personality and Social Psychology, 51(6), 1173. https://doi.org/10.1037/0022-3514.51.6.1173

Bhattacherjee, A. (2012). Social science research: Principles, methods, and practices. Global Text Project. Retrieved from https://scholarcommons.usf.edu/oa_textbooks/3

Blanchard, L., Hinnant, C., \& Wong, W. (1998). Market-based reforms in government: toward a social subcontract? Administration and Society, 30(56), 483-512. https://doi.org/10.1177/0095399798305001 
Booth, D., \& Cammack, D. (2013). Governance for development in Africa: Solving collective action problems. London Uk: Zed Books Ltd.

Brinkerhoff, D. W. (2015). Public sector management reform in developing countries: Perspectives beyond NPM orthodoxy. Public Administration and Development, 35(4), 222-237. https://doi.org/10.1002/pad.1739

Bukenya, B., Hickey, S., \& King, S. (2017). The contextual factors that shape accountability: Institute of Development Policy and Management School of Evironment and Development. United Kingdom: The University of Manchester.

Castillo, J. (2008). Research population. Retrieved from http://www.experimentresources.com/research-

Cooper, D. R., \& Schindler, P. S. (2006). Business research methods (9th ed.). New York: McGraw- Hill.

Cortina, J. M. (1993). What is coefficient alpha? An examination of theory and applications. Journal of Applied Psychology, 78(1), 98-101. https://doi.org/10.1037/0021-9010.78.1.98

Creswell, J. W. (2014). Research Design: Qualitative, quantitative, and mixed methods approaches (4th ed.). New York: Sage Publications.

della Porta, D. (2013). Can democracy be saved?: Participation, deliberation and social movements. New York: John Wiley \& Sons. https://doi.org/10.1002/9780470674871.wbespm065

Domingo, P. (2015). Women's voice and leadership in decision-making: Assessing the evidence. London: ODI.

Doolittle, A., \& Faul, A. C. (2013). Civic Engagement Scale: A Validation Study. SAGE Open, 3(3). https://doi.org/10.1177/2158244013495542

Gaventa, J., \& Barrett, G. (2012). Mapping the outcomes of citizen engagement. World Development, 40(12), 2399-2410. https://doi.org/10.1016/j.worlddev.2012.05.014

Gbedemah, F. (2010). Management, uses and values of demand-Ooriented domestic water facilities in the Akatsi district of Ghana (Doctoral thesis). University of Leicester.

Goetz, A. M., \& Gaventa, J. (2001). Bringing Citizen Voice and Client Focus into Service Delivery IDS Working Paper (No. 138). Brighton.

Green, L., \& Kreuter, M. (1991). Health promotion planning: An educational and environmental approach. California: Mayfield Publishers, Mountain View.

Guijt, I., \& Shah, M. K. (1998). The myth of community: gender issues in participatory development. London: Intermediate Technology Publications. https://doi.org/10.3362/9781780440309

Hirschman, A. O. (1970). Exit, voice, and loyalty: Responses to decline in firms, organizations, and states (Vol. 25). Cambridge: Harvard university press. 
https://doi.org/10.2307/2325604

Hofstede, G., Hofstede, G. J., \& Minkov, M. (2005). Cultures and organizations: Software of the mind (Vol. 2). New York: McGraw- Hill.

Joseph, A. B. (2016). Effective Communication Skill as a Tool for Effective Service Delivery Being a Paper presented at a Refresher Course for Secretaries, Protocol Officers, Court Registrars, Process Clerks and Bailiffs At National Judicial Institute, Abuja . By Abuja . E.

Karakos, H. L. (2015). Understanding civic engagement among youth in diverse context. Unpublished PhD Thesis, University of Vandebilt- Ghana.

Katz, N., Lazer, D., Arrow, H., \& Noshir, C. (2004). Network theory and small groups. Small Group Research, 35, 307-332. https://doi.org/10.1177/1046496404264941

Kawa, I. H. (2003). Assessment of the prospects of improved service delivery at sub-district level within the framework of the local government reform programme: A study of Kondoa District Council. The 8th Annual REPOA Research Workshop, White Sands Hotel. Dar es salaam.

Kessy, F., \& Mahali, R. (2016). Water, Sanitation and Hygiene Services in Tanzania: Access, Policy Trends and Financing.

Kothari, C. R. (2004). Research methodology: Methods and techniques. Mumbai: New Age International $(\mathrm{P})$ Ltd.

Leighninger, M. (2005). The recent evolution of democracy. National Civic Review, 94(1), 17-28. https://doi.org/10.1002/ncr.79

Lu, Y. (2009). Challenges for China's international communication. United Kingdom: University of Nottingham. Madzivhandila, T.S.

Lührmann, A., Marquardt, K. L., \& Mechkova, V. (2017). Constraining governments: New indices of vertical, horizontal and diagonal accountability. https://doi.org/10.2139/ssrn.2956464

Malena, C., Forter, R., \& Singh, J. (2004). Social Accountability: An introduction to the concept and Emerging practice. Washington, D.C.: The World Bank Social Development.

Meinzen-Dick, R., DiGregorio, M., \& McCarthy, N. (2004). Methods for studying collective action in rural development. Agricultural Systems, 82(3), 197-214. https://doi.org/10.1016/j.agsy.2004.07.006

Mkonda, M. Y. (2015). Assessment of water shortage and its implications to gender role in semi-arid areas in Mvumi Ward, Dodoma in Tanzania. Arts Social Sci J, 66(142), 2.

Mollah, M. A. H. (2008). Bureaucracy and accountability: the case of Bangladesh. International Journal on Governmental Financial Management, 8(1), 87-100.

Mugumya, F. (2013). Enabling community-based water management systems: governance and sustainability of rural point-Water facilities in Uganda. PhD thesis, Dublin City. 
Mulgan, R. (2000). Accountability: An Ever-Expanding Concept? Public Administration, 78(3), 555-573. https://doi.org/10.1111/1467-9299.00218

Munjuri, M. G. (2013). Human capital, social capital, employee empowerment, quality of decisions and performance of commercial banks and insurance firms in Kenya (Doctoral thesis). University of Nairobi.

Muriu, A. R. (2014). How does Citizen Participation impact Decentralized Service Delivery? Lessons from the Kenya Local Authority Service Delivery Action Plan. Devolution and Public Policy Consultant in Kenya, 3-23. https://doi.org/10.1144/0016-76492008-136

Mwamaso, A. (2015). Measuring and mapping citizens' access to rural water supply in Tanzania (PhD Thesis). The University of Twente.

Naidoo, C. (2017). A framework for optimising public participation for effective municipal service delivery (Doctoral thesis). University of South Africa, Doctor of Business Leadership (DBL).

National Bureau of Statistics. (2017). Uninted Republic of Tanzania National Panel Survey Wave 4, 2014 - 2015. Dar es salaam: Ministry of Finance and Planning Dar es Salaam.

Nganyanyuka, K. O. (2017). Seeing Like a Citizen: Access to Water in Urban and Rural Tanzania (Doctoral Thesis). The University of Twente, Enschede, Netherlands. https://doi.org/10.4324/9780429279171-14

Nguyahambi, A. M., \& Chang'a, H. H. (2019). Social accountability monitoring as an approach to promoting active citizenship in Tanzania. In K. Holma \& T. Kontinen (Eds.) (2019). Practices of Citizenship in East Africa. London: Routledge.

Olomola, A. S., Simbine, A. T., Wadinga, A., \& Adeagbo, A. (2012). Accountability and performance of government agencies in the delivery of water, education and road services in Nigeria. Ibadan Nigeria.

Olson, M. (1965). The theory of collective action: public goods and the theory of groups. Cambridge: Harvard university press.

Oluoch, D. (2014). The moderating effect of employee engagement in the relationship between strategic planning and organization performance (Doctoral thesis). United States International University-Africa.

Opoku-agyeman, C. (2013). Civic engagement and Ghana's Fourth Republic: Implications for Public Policy. Unpublished PhD Thesis University of Akrian, Ghana.

Ostrom, E. (1996). Crossing the great divide: Coproduction, synergy, and development. World Development, 24(6), 1073-1087. https://doi.org/10.1016/0305-750X(96)00023-X

Ostrom, E. (2010). Analyzing collective action. Agricultural Economics, 41(1), 155-166. https://doi.org/10.1111/j.1574-0862.2010.00497.x

Patton, M. Q. (1990). Qualitative evaluation and research methods (2end ed.). London: Sage 
Publications.

Peiffer, C., \& Marquette, H. (2015). Theoretical (Mis) understanding? Applying principal-agent and collective action theories to the problem of corruption in systemically corrupt countries. In Ethics in public policy and management: A global research companion (pp. 109-126). https://doi.org/10.4324/9781315856865-7

Prokopy, L. S. (2005). The relationship between participation and project outcomes: Evidence from rural water supply projects in India. World Development, 33(11), 1801-1819. https://doi.org/10.1016/j.worlddev.2005.07.002

Sargsyan, G. (2016). Democracy and development in the making. Civic participation in Armenia: Challenges, opportunities. Unpublishe PhD Thesis University of Trento.

Sarker, A. E. (2008). Patron-client politics and its implications for good governance in Bangladesh. International Journal of Public Administration, 31(12), 1416-1440. https://doi.org/10.1080/01900690802194966

Sarker, S. (2011). The role of communication and trust in global virtual teams: A social network perspective. Journal of Management Information Systems, 28(1), 273-310. https://doi.org/10.2753/MIS0742-1222280109

Saunders, M., Lewis, P., \& Thornhill, A. (2012). Research methods for business students (6th ed.). Edinburgh: Pearson education.

Sharma, B. (2008). Voice, accountability and civic engagement: A conceptual overview. Paper Commissioned by Oslo Governance Centre, Bureau for Development Policy, United Nations Development Programme. Overseas Development Institute,. London.

Silverman, D. (2006). Interpreting qualitative data:Methods for talk, text and interaction. Berlin Heidelberg: Sage Springer.

Tshoose, C. I. (2015). Dynamics of public participation in local government: A South African perspective. African Journal of Public Affairs, 8(2), 626-630. Retrieved from https://repository.up.ac.za/bitstream/handle/2263/58158/Tshoose_Dynamics_2015.pdf?seque nce $=1 \&$ isAllowed $=y$

UNICEF. (2015). Water and Sanitation Budget Brief FY 2011/12- FY 2015/16. Retrieved from www.unicef.org/tanzania/

United Nation. (2008). People Matter: Civic Engagement in Public Governance. New York: United Nations Department of Economic and SocialAffairs.

United Republic of Tanzania. (2002). National Water Policy Dar es Salaam: Ministry of Water and Livestock Development.

Wahab, E. A. (2011). Civic Education: A recipe for promoting responsible citizenry in Nigeria. Nigeria Journal of Social Studies, 14(2), 175-186.

Yamane, T. (1967). Statistics: An introductory analysis (2nd ed.). New York: Haper and Row. 


\section{Copyright Disclaimer}

Copyright for this article is retained by the author(s), with first publication rights granted to the journal.

This is an open-access article distributed under the terms and conditions of the Creative Commons Attribution license (http://creativecommons.org/licenses/by/4.0/). 